\title{
WHAT ARE ENGINEERS LEARNING FROM INSECTS?
}

\author{
BASED AT TEMPLE UNIVERSITY IN THE US, PROFESSOR PARSAORAN \\ HUTAPEA AND HIS MECHANICAL ENGINEERING RESEARCH TEAM \\ HAVE TAKEN INSPIRATION FROM HONEYBEE AND MOSQUITO \\ STINGERS TO DESIGN A NEW SURGICAL NEEDLE THAT IS MORE \\ ACCURATE AND LESS LIKELY TO CAUSE TISSUE DAMAGE
}

\section{TALK LIKE A MECHANICAL ENGINEER}

SURGICAL NEEDLE - a type of needle used in surgical procedures, which is usually long, thin and hollow and may be used to inject treatments into a specific area of the body or to remove cells that are then tested to diagnose a patient's condition

SIDE EFFECT - an unintended, and usually unwanted, effect of a particular intervention

BIOINSPIRED - new materials or devices with designs inspired by nature, and particularly species' adaptations, which could act as solutions to human problems

BARB - a sharp point, such as on barbed wire
ASYMMETRIC - something that is not symmetrical

DYNAMIC - something that is moving, as opposed to static (still)

FREQUENCY - the rate of something, such as the number of vibrations per second

3D PRINTING OR MANUFACTURING - a method of creating a three-dimensional object layer by layer based on a digital design

PROTOTYPE - an early sample or model of a new design, used to test how well the design works
Surgical needles are used by doctors to diagnose and treat patients with a variety of conditions. For example, brachytherapy is one of the most successful types of radiotherapy where a surgical needle is used to target cancer cells with radiation, which stops the cells from dividing and growing. However, procedures like brachytherapy require high levels of precision to be successful. If the surgical needle accidentally passes through sensitive tissues like bones, arteries or organs, or bends and moves tissues, there can be harmful side effects for the patient.

Parsaoran (Chai) Hutapea is a professor of mechanical engineering and Director of Composite Laboratory and the Nanoscale Instrumentation Center at Temple University in the US. Chai is using his expertise in engineering, as well as inspiration from insects, to design better surgical needles that require less force to be inserted and could, therefore, reduce tissue damage in patients who need procedures like brachytherapy.

WHAT CAN WE LEARN FROM INSECTS TO IMPROVE SURGICAL NEEDLES?

Researchers often look to nature for innovative solutions to scientific challenges, making new bioinspired devices and materials. Different species have adaptations which are perfectly suited to performing specific tasks. For example, honeybees have sophisticated stingers used as a defence against predators. It was these barbed stingers that interested Chai and his team as they thought about how to reduce the insertion force of surgical needles. A lower insertion force means that a needle is less likely to bend or to move the tissue it is passing through. It would, therefore, cause less damage to tissues and is more likely to be on target. "It is counterintuitive, but the barbed structure actually helps to reduce the amount of force needed to insert the needle and reduce tissue damage," says Chai. Decreasing insertion force could reduce pain, trauma and swelling caused by needles and, potentially, reduce a patient's recovery time.

However, honeybee stingers do not provide the perfect model surgical needle. One reason for this is that stingers are asymmetric, which reduces accuracy when stinging a target. This does not matter too much for honeybees as 

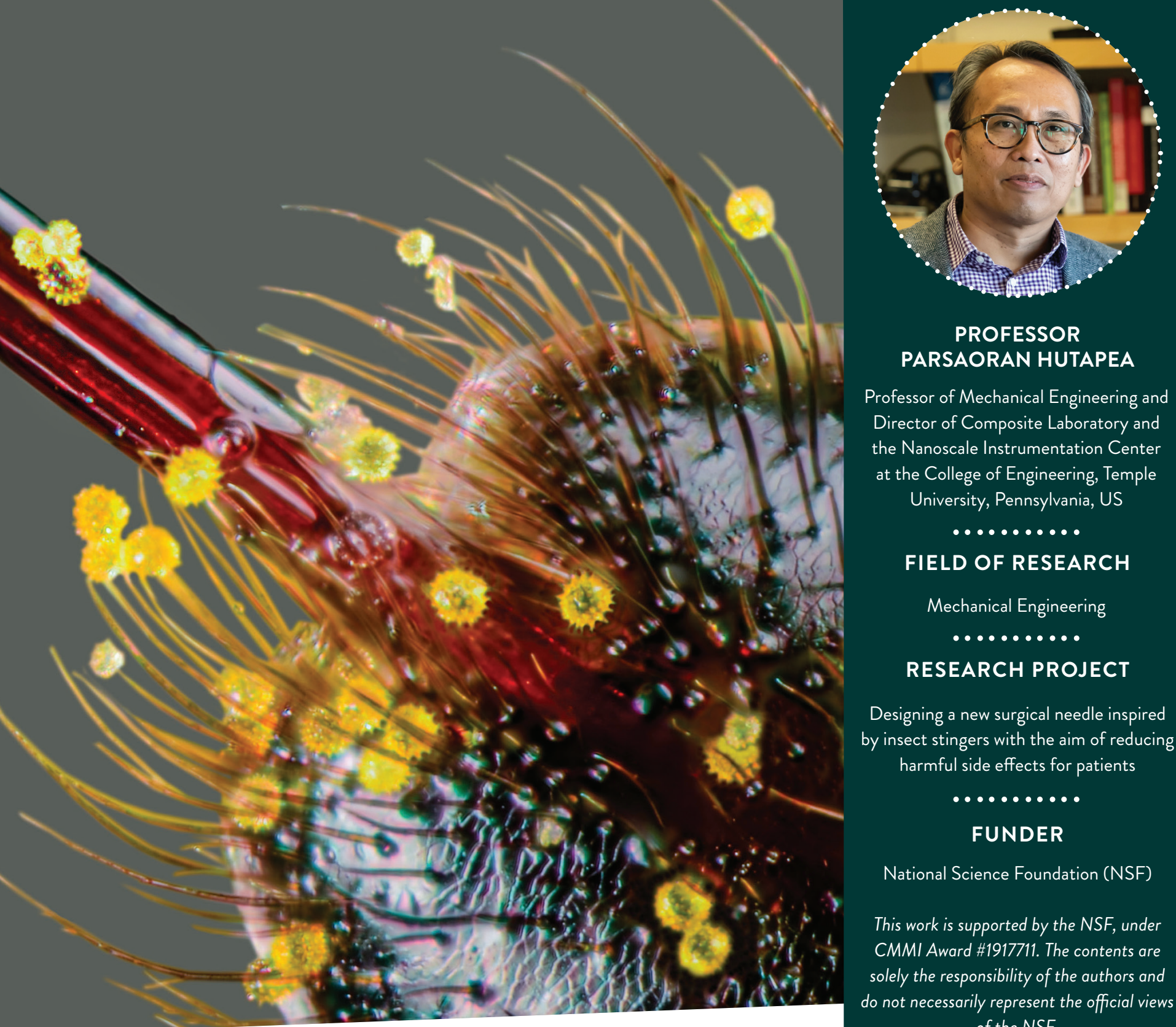

\section{PROFESSOR \\ PARSAORAN HUTAPEA}

Professor of Mechanical Engineering and

Director of Composite Laboratory and the Nanoscale Instrumentation Center at the College of Engineering, Temple

University, Pennsylvania, US

\section{FIELD OF RESEARCH}

Mechanical Engineering

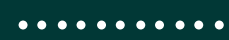

\section{RESEARCH PROJECT}

Designing a new surgical needle inspired by insect stingers with the aim of reducing harmful side effects for patients

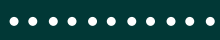

\section{FUNDER}

National Science Foundation (NSF)

This work is supported by the NSF, under CMMI Award \#1917711. The contents are solely the responsibility of the authors and do not necessarily represent the official views of the NSF.

they just need to sting a predator somewhere on its body. Placement accuracy is, however, very important for surgical needles, which need to reach specific tissues and cells, so they must be symmetrical to be more easily controlled by a surgeon.

HOW DO YOU TEST WHETHER A BIOINSPIRED NEEDLE CAN BE USED ON A HUMAN PATIENT?

"First, we designed and 3D-manufactured the bioinspired needle," explains Chai. The 3D-printed prototype needle was then inserted into an insertion test set up, also designed by Chai and his team. The insertion test setup includes a plastic gel - or in some experiments, animal tissues - which mimics the properties of human tissues, and sensors that can calculate the force of the needle as it is being inserted and pulled out of the gel. This provides a measure of the tissue damage that would be caused by the needle. Other things like deflection (how far the needle strays from its intended target) were also measured.

Chai and his team tested inserting the surgical needle into the gel or animal tissues while it was vibrating (dynamic) and when it was not (static). The idea for dynamic needle insertion was also inspired by insects. Chai says, "Insects sting with vibration, so we mimic what they do." The tests found that the needle performed better when it was vibrating. "At certain frequencies, vibration helps to reduce the insertion force of the needle on tissues and thus decreases the damage," he explains. The needle also has a special coating to reduce the friction between it and human tissue, which was also found to reduce insertion force and tissue damage.

WHAT IS THE HARDEST THING ABOUT DESIGNING NEW SURGICAL NEEDLES? Such precise mechanical engineering comes with challenges. Surgical needles are used in many different parts of the body and in different tissues, so there is no 'one size fits all' solution to designing new ones. Chai explains, "One can understand specific needle mechanics in one tissue in the lab, but it is extremely difficult to understand the many factors related to different tissues. More research is needed to study needle mechanics in a wide range of tissue types."

WHAT IS THE NEXT STEP FOR BIOINSPIRED SURGICAL NEEDLES?

Chai and his team have successfully demonstrated in a lab that their bioinspired needle reduces insertion force compared with conventional surgical needles. They are now testing their needle prototypes - which are about $2 \mathrm{~mm}$ wide - on live pigs. The next major stage of the work is to $3 \mathrm{D}$ print a $1 \mathrm{~mm}$ wide metal version of the needle, the kind that could be used on humans in the future. 


\section{ABOUT MECHANICAL ENGINEERING}

Mechanical engineers combine physics, maths and materials science to design, build, test and maintain objects with moving parts. Mechanical engineers can work on all sorts of products from aeroplanes to robotics to medical devices.

WHAT ARE THE REWARDS OF MECHANICAL ENGINEERING? There is a lot of creativity in mechanical engineering, as researchers produce their own designs and test their hypotheses. In addition, mechanical engineers often collaborate with people working in other fascinating areas of science and research. Chai works with medical scientists and radiologists, amongst many other experts.
WHAT DOES THE NATURAL WORLD HAVE TO DO WITH MECHANICAL ENGINEERING?

Insects and other animals are natural mechanical systems. Chai explains, "Humans have created and designed cars, trains, planes, medical devices, and much more - but nature provides inspiration that we have not yet explored fully, which could be used to improve human-made mechanical systems."

WHICH PROBLEMS WILL MECHANICAL ENGINEERS BE SOLVING IN THE FUTURE? Mechanical engineers have a vital role to play in addressing the world's biggest challenges, such as climate change. "We should study nature and learn new ways to create a more efficient and sustainable mechanical system - whether it is a car, a train, a coffee machine, or a medical device," says Chai.

\section{PATHWAY FROM SCHOOL TO MECHANICAL ENGINEERING}

- Mechanical engineering uses principles from maths and physics and it is usually required that you study one or both subjects, and perhaps another science subject, at college to be admitted to a university course in mechanical engineering.

\section{EXPLORE A CAREER IN MECHANICAL ENGINEERING}

- There are many organisations around the world that provide information and resources about mechanical engineering, and even opportunities for internships. Chai recommends exploring the following websites:

The American Society of Mechanical Engineers in the US: www.asme.org Institution of Mechanical Engineers in the UK: www.imeche.org

- The College of Engineering at Temple University runs outreach schemes for young people, such as summer programmes for high school students: engineering.temple.edu

Universities elsewhere run similar programmes, so find out what is going on in your local area!

- According to Salary.com, salaries for mechanical engineers in the US range from around $\$ 66,000$ as a starting salary to a mean of $\$ 112,000$. The top earners in mechanical engineering have an annual salary of around $\$ 158,000$.

www.salary.com/research/salary/general/mechanical-engineer-salary

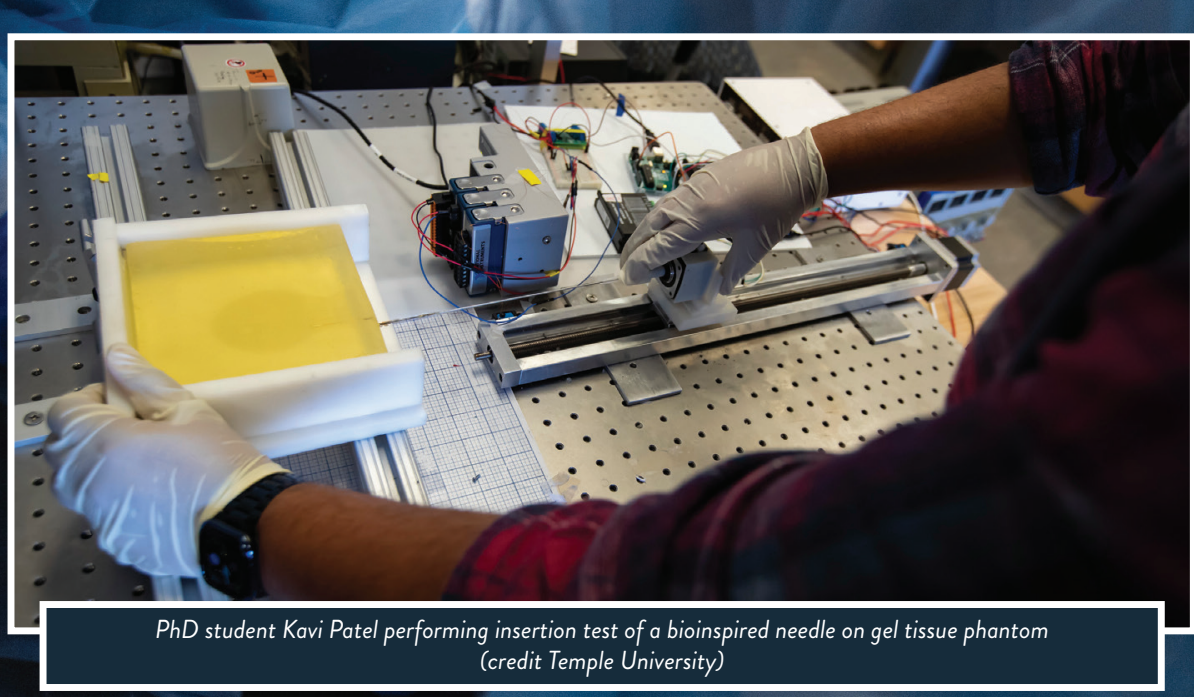

Chai recommends that you learn other subjects that interest you - be it biology, history, English or foreign languages. "Learn a range of things to be a wellrounded person and engineer," he says.

-After studying mechanical engineering, you may go on to become a licensed engineer. There is more information about this process in the US here:

www.asme.org/topics-resources/content/ the-path-to-professional-licensure

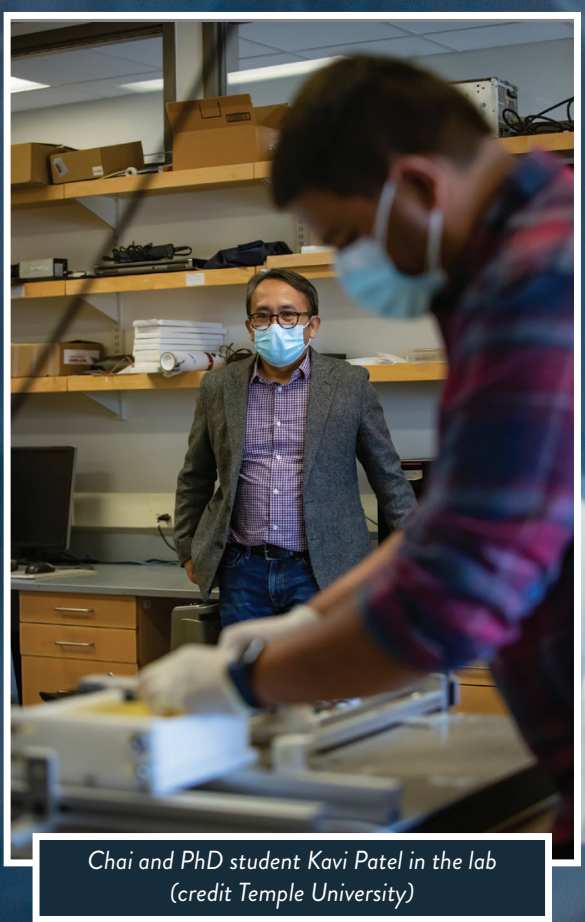




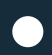 HOW DID CHAI BECOME A MECHANICAL ENGINEER?}

WHAT WERE YOUR INTERESTS WHEN YOU WERE GROWING UP? I wanted to be a soccer (football) player!

WHAT INSPIRED YOU TO BECOME A MECHANICAL ENGINEER?

Looking back, I really don't know! It just happened that I liked it.

HOW HAS BEING A MECHANICAL ENGINEER CHANGED THE WAY YOU THINK?
I can think more critically and make links between seemingly unrelated things - for example, thinking about how the movement of an animal relates to a mechanical system.

\section{WHAT ARE YOUR PROUDEST} CAREER ACHIEVEMENTS AND HOPES FOR THE FUTURE?

I feel very proud to see my students succeed in their careers. Of course, my future ambition is to see one of my devices used in hospitals!

\section{CHAI'S TOP TIPS}

\section{Do not be afraid to fail.}

02 Be explorative to find out what you like - enjoy reading books that interest you and go to parties with interesting people!

\section{MEET DOYOUNG}

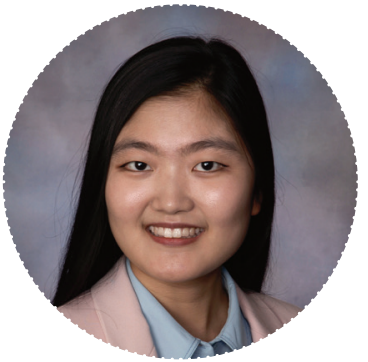

DOYOUNG KIM PHD STUDENT

Doyoung is conducting her $\mathrm{PhD}$ research in Chai's lab.

WHAT IS A TYPICAL DAY LIKE FOR YOU?

I usually attend university classes, study independently and read research papers related to my research. Sometimes, I attend lab meetings and work in the lab office.

\section{HOW HAS YOUR}

EDUCATION LED YOU TO

\section{THIS RESEARCH?}

I was determined to find something I was interested in, so, as a younger student, I took a range of classes and did internships in different fields. Having an open mind, exploring different areas and looking for what really intrigued me led to this research.

\section{WHAT WERE YOUR} INTERESTS WHEN YOU WERE GROWING UP? When I was younger, I was interested in creative activities such as dancing, painting, martial arts (Tae-kwon-do) and crafting. As I moved into middle school, I got into maths and science, especially physics. I enjoyed working in labs and doing hands-on work.

\section{WHO OR WHAT INSPIRED YOU TO BECOME AN \\ ENGINEER?}

My dad, who is also a mechanical engineer, was my role model. When I was in middle school, my dad brought a lot of scratch papers from his work, so I could see complex equations and machine drawings, but I didn't fully understand them back then! My curiosity about his work led me to engineering and when I had to choose my major, he gave me lots of advice. He explained that mechanical engineering has various branches, so would enable me to explore different areas until I found the one right for me.

\section{WHAT ATTRIBUTES HAVE} MADE YOU SUCCESSFUL? My habit of asking questions! Engineers are problem solvers, and we cannot answer questions if we don't ask questions. Also, I am not afraid of asking for feedback, as well as reviewing what l've done wrong. I have always studied hard and reviewed my mistakes in order to improve.

\section{WHAT DOES IT FEEL LIKE} TO BE THE RECIPIENT OF TEMPLE UNIVERSITY'S 2021 PRESIDENTIAL FELLOWSHIP?

I am honoured to have received this fellowship, which my advisor, Professor Hutapea, nominated me for. I had two internships at medical device companies that led to my research focus of medical device design, which led me to receiving this award. As this is such a prestigious award, I feel proud of myself but, at the same time, I feel responsible. More than ever, I am determined to do my best to be a successful PhD student.

\section{HAVE THERE BEEN ANY EUREKA MOMENTS IN YOUR CAREER?}

When I was doing an internship at a dental X-ray medical device company, I had to design a headrest that would satisfy both patients and engineers. I researched various mechanisms and watched online videos, but, for a few days, I was struggling to find inspiration. Two days before a progress meeting, I was staring at a headrest for about 20 minutes and, suddenly, a mechanism popped into my head! I completed my design and the meeting was a success. This goes to show, you need to be patient and keep focused - the ideas will come.

WHAT ARE YOUR AMBITIONS FOR THE FUTURE?

I want to use my knowledge to contribute to a better world. I would like to be a leader and an innovator of creative research in my field. Lastly, I want to be an educator, so I can help students find their own path in becoming influential scholars and engineers.

WHAT IS YOUR TOP TIP FOR YOUNG PEOPLE HOPING TO FOLLOW IN YOUR FOOTSTEPS?

I know it is hard, but it is helpful to know what you are interested in. To know this, it is important to try different things, so I would encourage people to explore various areas. Don't be afraid, be adventurous! 